\title{
Tumor Necrosis Factor Receptor Superfamily Member 27
}

National Cancer Institute

\section{Source}

National Cancer Institute. Tumor Necrosis Factor Receptor Superfamily Member 27. NCI

Thesaurus. Code C159366.

Tumor necrosis factor receptor superfamily member 27 (297 aa, $\sim 33 \mathrm{kDa}$ ) is encoded by the human EDA2R gene. This protein plays a role in the development and maintenance of ectodermally derived tissues. 